\title{
Membiasakan Cuci Tangan Pakai Sabun Pada Masyarakat Saat Pandemi COVID-19 di Kompleks Perumahan Kota Samarinda
}

\author{
Muhammad Sultan', La Ode Khairul Zikri ${ }^{2}$ \\ 1,2Fakultas Kesehatan Masyarakat, Universitas Mulawarman, Samarinda, Indonesia \\ e-mail: sultan_kajang81@yahoo.co.id
}

\begin{abstract}
Abstrak
Membiasakan diri mencuci tangan pakai sabun dengan air mengalir saat pandemi COVID-19 merupakan salah satu protokol kesehatan yang harus diterapkan untuk mencegah penyebaran COVID-19 di masyarakat. Praktik tersebut diharapkan bukan hanya selama pandemi COVID-19, akan tetapi dapat menjadi kebiasaan sehari-hari masyarakat bahkan setelah COVID-19. Program pengabdian ini bertujuan untuk meningkatkan perilaku hidup bersih dan sehat masyarakat melalui simulasi atau demonstrasi dan pemberian video cara mencuci tangan. Masyarakat di kompleks perumahan Kota Samarinda terbukti mampu mempraktikkan langkah mencuci tangan yang benar sesuai dengan rekomendasi badan kesehatan dunia. Kegiatan ini dapat meningkatkan pengetahuan dan praktik masyarakat dalam mencuci tangan yang benar sehingga disarankan agar kegiatan serupa dapat dilaksanakan di daerah lainnya dengan mempertimbangkan karakteristik sasaran promosi kesehatan.
\end{abstract}

Kata Kunci: Cuci Tangan, COVID-19, Masyarakat, Perumahan

\begin{abstract}
Getting used to washing hands with a soap with running water during the COVID-19 pandemic is one of the healths protocols that must be implemented to prevent the spread of the COVID19 in the community. This practice is expected not only during the COVID-19 the pandemic, but can become people's daily habits even after COVID-19. This service program aims to improves the clean and healthy lifestyle of the community through simulations or demonstrations and providing videos on how to wash hands. The community in the Samarinda City the housing complex is proven to be able to practice the correct hand washing steps according to the recommendations of the world health agency. This activity can increase community knowledge and a practice in proper hand washing so, it is suggested that similar activities can be carried out in other areas by taking into an account the characteristics of health promotion target.
\end{abstract}

Keywords: Washing hands, COVID-19, Community, Housing

\section{Pendahuluan}

Perilaku mencuci tangan dengan sabun atau biasa dikenal dengan CTPS pada air mengalir merupakan salah satu praktik masyarakat yang mencerminkan perilaku hidup bersih dan sehat (PHBS). Selama pandemi Coronavirus Disease (COVID-19) 
berlangsung, perilaku CTPS masyarakat menjadi komponen penerapan protokol kesehatan untuk memutus rantai penularan dan penyebaran COVID-19 di masyarakat. Belum diketahuinya secara pasti kapan COVID-19 akan berakhir, maka diperlukan upaya pencegahan COVID-19 melalui protokol kesehatan yang dilaksanakan secara ketat, konsisten dan berkelanjutan.

Badan kesehatan dunia (World Health Organization) merekomendasikan ke semua negara di dunia agar menyediakan akses sarana kebersihan tangan dan mengharuskan penggunaannya terutama pada fasilitas umum untuk mencegh penularan COVID-19 (WHO, 2020c). Bahkan, jauh sebelum kemunculan COVID-19, WHO telah merekomendasikan tentang tata cara CTPS yang benar agar terhindar dari penyakit menular melalui tangan (WHO, 2009). Pada masa pandemi ini, WHO juga telah menyarankan agar setiap orang membersihkan tangannya sesering mungkin dengan pembersih tangan jika tangan tidak terlihat kotor atau dengan sabun dan air jika tangan kotor (WHO, 2020a).

Perilaku CTPS dengan air mengalir secara benar yang dipraktikkan dalam keseharian bukan tanpa alasan karena berbagai penyakit dan gangguan kesehatan seperti diare dan penyakit pernapasan dapat menyerang seseorang jika tidak mempraktikkan CTPS dengan benar. Oleh karena itu, praktik CTPS dengan air mengalir secara konsisten dan sering sangat dibutuhkan khususnya masa pandemi COVID-19 saat ini. Pandemi COVID-19 selain berdampak buruk bagi status kesehatan masyarakat dan perekonomian serta sektor kehidupan lainnya, juga dapat berdampak positif pada peningkatan perilaku PHBS seseorang. Terbukti terjadi peningkatan secara signifikan masyarakat dalam mengingat dan mempraktikkan CTPS saat pandemi COVID-19 dibandingkan sebelum pandemi (Haston et al., 2020).

Berbagai upaya pemerintah yang telah dilaksanakan dalam meningkatkan kepatuhan masyarakat menerapkan protokol kesehatan termasuk praktik CTPS masyarakat, namun masih ditemukan masyarakat yang belum membiasakan diri mencuci tangan. Hasil penelitian tentang perilaku masyarakat di masa pandemi COVDI-19 yang dilakukan oleh Biro Pusat Statistik menunjukkan bahwa masih ditemukan 24,62 \% masyarakat yang tidak patuh mencuci tangan dengan benar (Tim BPS Covid-19 Statistical Task Force, 2020).

Dibutuhkan intervensi program kesehatan yang bertujuan untuk meningkatkan perilaku masyarakat agar tetap patuh pada protokol kesehatan termasuk konsisten dalam CTPS dan air mengalir. Promosi kesehatan dengan menggunakan berbagai media komunikasi kesehatan dapat meningkatkan pengetahuan tentang CTPS (Mulia, 2018). Kegiatan sosialisasi CTPS pada masyarakat berdampak pada pengetahuan masyarakat tentang CTPS yang benar dan meningkatkan kesadaran masyarakat untuk membiasakan CTPS dalam kesehariannya (Sinaga et al., 2020).

Semua pihak dapat berpartisipasi dalam mendorong masyarakat untuk berperilaku PHBS termasuk perguruan tinggi. Program pengalaman belajar lapangan merupakan peran nyata perguruan tinggi dalam meningkatkan perilaku kesehatan masyarakat yang lebih baik. Masyarakat yang terbiasa hidup bersih dan sehat secara konsisten dan terus-menerus merupakan faktor penting untuk mencapai derajat kesehatan 
masyarakat setingi-tingginya. Kebiasaan CTPS pada masyarakat tidak hanya berlaku saat pandemi COVID-19, tetapi dapat dipraktikkan dalam kehidupan sehari-hari setelah pandemi COVID-19 berlalu.

\section{Metode}

Kegiatan ini merupakan rangkaian program pengalaman belajar lapangan mahasiswa di Fakultas Kesehatan Masyarakat Universitas Mulawarman yang dilaksanakan pada bulan November 2020 di Rukun Tetangga 036 Kelurahan Karang Asam Ulu Kota Samarinda tepatnya di Kompleks Perumahan Green Point Kavling Sapphire. Kegiatan simulasi dan pemberian video dilaksanakan pada tanggal 23-27 November 2020 pada 34 kepala keluarga. Simulasi cara CTPS dengan air mengalir dilakukan secara langsung yaitu mengunjungi rumah warga dan pembagian video melalui Whatsapp grup warga di kompleks perumahan tersebut. Evaluasi perilaku CTPS dengan air mengalir dilaksanakan melalui observasi langsung pada saat masyarakat mempraktikkan CTPS.

\section{Hasil dan Pembahasan}

Pada tahapan persiapan dimuai dengan menemui RT 036 setempat untuk menyampaikan maksud dan tujuan kedatangan tim PBL. Ketua RT menyambut baik kegiatan yang akan dilaksanakan tim PBL di kompleks perumahan. Setelah ditentukan jadwal, selanjutnya tim menyempatkan diri keliling kompleks bersama RT setempat menyapa warga dan sekaligus menyampaikan bahwa pada tanggal 23-27 November 2020 akan kami kunjungi kembali. Tim juga meminta izin ke pihak keamanan kompleks bahwa pada tanggal tersebut akan diadakan kunjungan ke rumah warga di kompleks untuk diadakan sosialisasi CTPS.

Tahapan selanjutnya adalah tahapan pelaksanaan kegiatan. Video mengenai cara CTPS yang benar telah diberikan kepada RT setepat untuk disebarluaskan ke warga kompleks melalui Whatsapp grup. Tim melakukan kunjungan ke rumah warga dengan menerapkan protokol kesehatan sebagaimana telah disepakati bersama dengan RT setempat. Setiap hari sekitar 5-6 rumah yang dikunjungi untuk mempraktikkan CTPS yang benar berdasarkan rekomendasi WHO (WHO, 2020b). Setiap warga yang dikunjungi diberikan kesempatan awal untuk mempraktikkan cara CTPS dengan air mengalir. Tim melakukan penilaian pada saat warga mempratikkan CTPS dan sebagian besar belum mengetahui secara benar CTPS sehingga diberikan simulasi tata cara CTPS yang benar. Setelah itu warga diminta kembali untuk mempraktikkan CTPS dan hasilnya warga mempraktikkan secara benar CTPS dan air mengalir. 

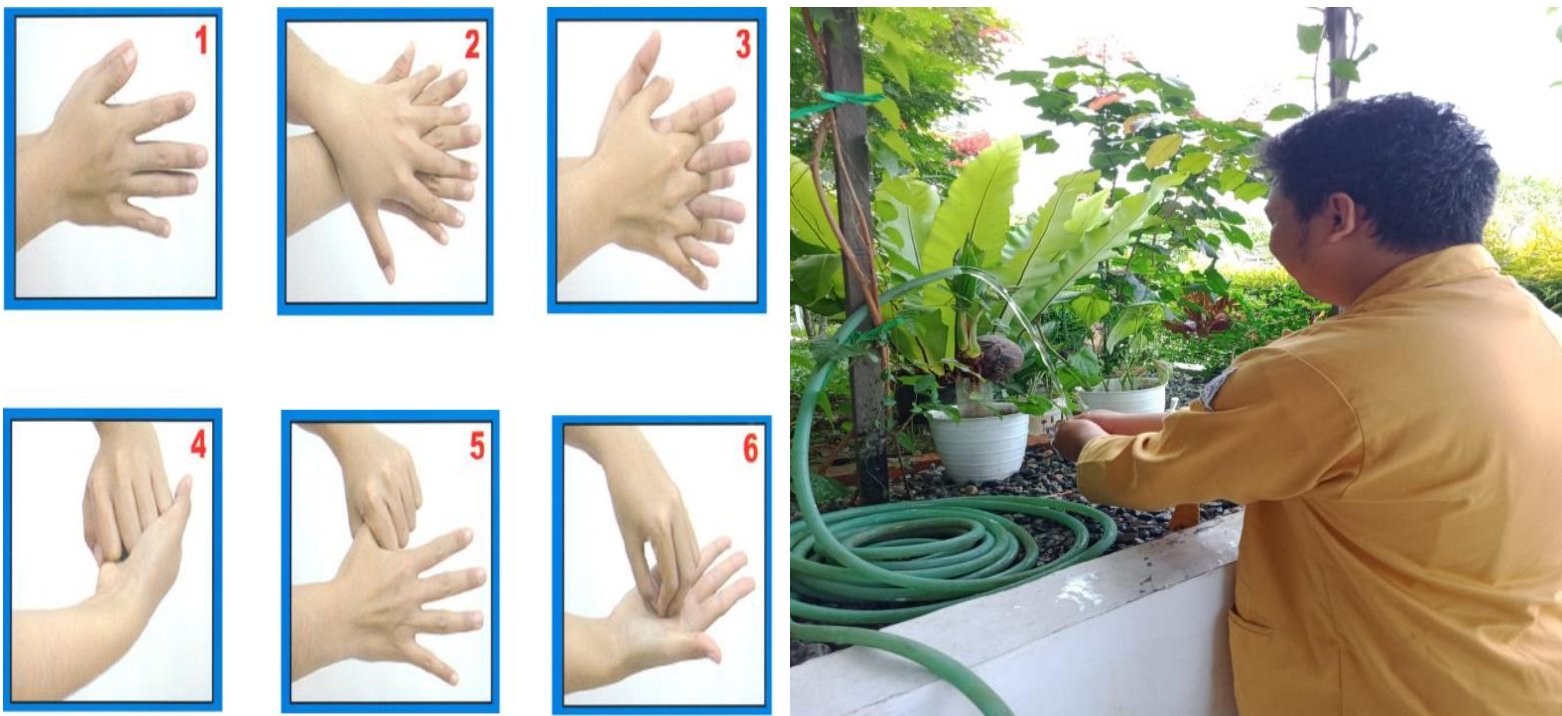

Gambar 1. Langkah-langkah dan simulasi CTPS

Warga yang bermukim di kompleks perumahan mengaku senang karena selama ini mencuci tangan tidak mengikuti langkah-langkah yang direkomendasikan. Penilaian yang dilakukan oleh tim PBL saat warga mempraktikkan CTPS dan hasilnya menunjukkan bahwa semua warga telah mempraktikkan CTPS secara benar setelah diberikan simulasi oleh tim PBL. Warga juga menyampaikan terima kasih karena telah dibagikan video CTPS karena menurutnya jika suatu hari lupa maka akan terbantu dengan video yang telah disebarluaskan melalui Whatsapp grup kompleks perumahan.
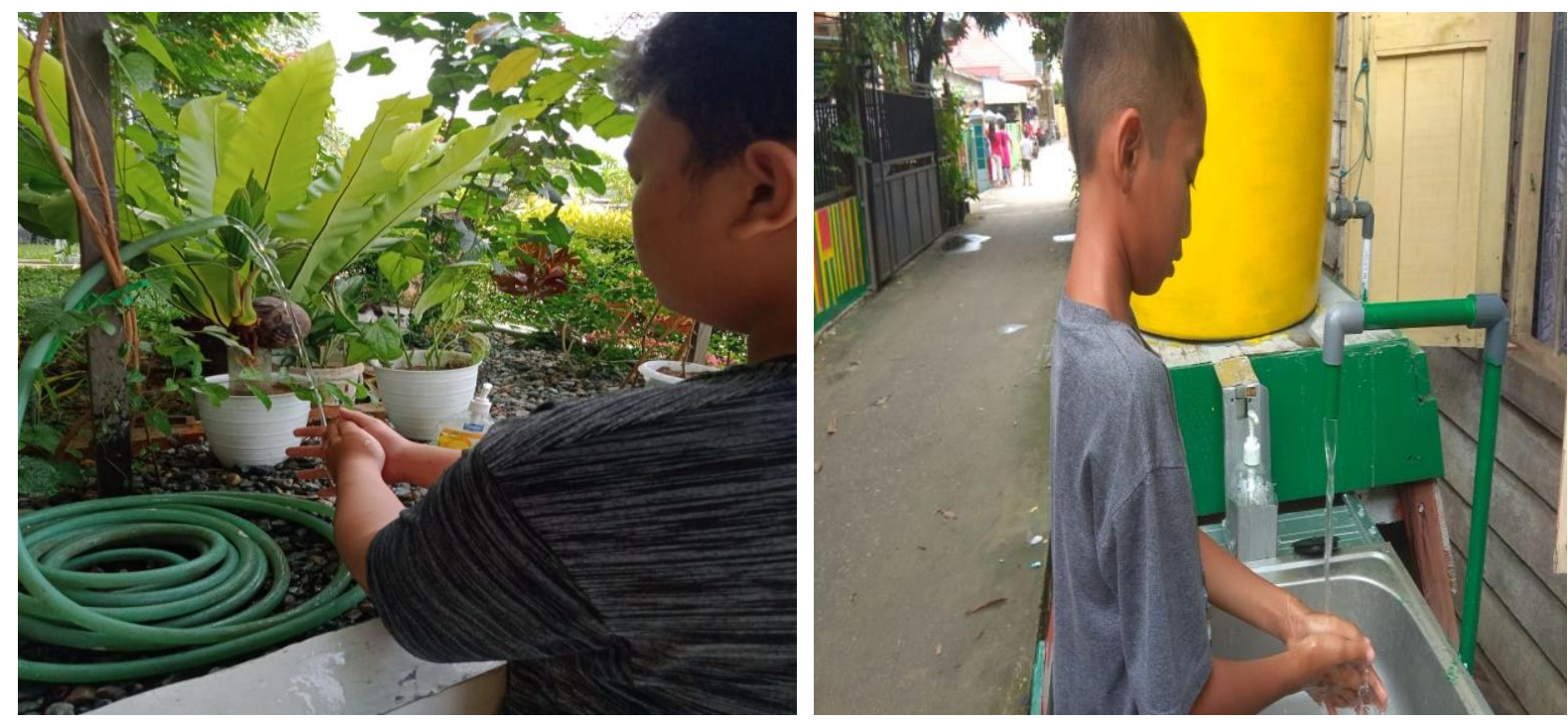

Gambar 2. Praktik CTPS masyarakat setelah dilakukan simulasi

CTPS dan air mengalir merupakan sesuatu yang terdengar gampang, akan tetapi masih ditemukan masyarakat yang tidak mempraktikkan secara benar. Adapun 
langka-langkah CTPS dengan air mengalir sesuai rekomendasi WHO antara lain; menggunakan sabun dan ditaruh di telapak tangan lalu basahi tangan dan menggosok telapak tangan yang sudah disabun tersebut. Selanjutnya menggosok punggung tangan dan jari lalu membersihkannya dengan posisi gerakan yang saling mengunci. Setelah itu dilanjutkan dengan membersihkan jari jempol dan ujung jari tangan secara bergantian lalu dikeringkan (WHO, 2020b).

Praktik CTPS dengan air mengalir secara benar dapat dipengaruhi beberapa faktor seperti pengetahuan seseorang tentang CTPS (Kartika et al., 2016), (Rahma Yunita Amar, 2019), (Mustikawati, 2016), (Taadi et al., 2019). Pengetahuan dan pemahaman seseorang yang kurang tentang CTPS dapat menyebabkan tingginya kasus penyebaran penyakit menular seperti diare, demam berdarah, penyakit kecacingan dan penyakit lainnya (Radhika, 2020) termasuk COVID-19 seperti yang terjadi hingga kini. Oleh karena itu, diperlukan upaya nyata dalam meningkatkan pengetahuan dan kesadaran masyarakat agar mereka mampu dan bersedia mempraktikkan CTPS dalam keseharianya.

Penyuluhan kesehatan disertai simulasi merupakan salah satu upaya untuk meningkatkan pengetahuan dan kesadaran masyarakat dalam mempraktikkan PHBS termasuk praktik CTPS dengan air mengalir (Kalsum, 2018). Penyuluhan kesehatan dapat dilakukan dengan menggunakan berbagai media dan salah satunya adalah audio visual video. Selain itu, metode simulasi atau demonstrasi cara CTPS yang benar terbukti dapat meningkatkan perilaku sebelum dan sesudah diberikan demonstrasi hingga $15 \%$ (Ambarwati \& Prihastuti, 2019). Selain itu, keterampilan seseorang dalam melakukan CTPS meningkat setelah dilakukan simulasi CTPS (Hartanti, Kurniawati, 2019).

Penggunaan media video dapat mempengaruhi peningkatan pengetahuan seseorang dalam CTPS dan air mengalir (Saputra \& Fatrida, 2019), (Ruby et al., 2015), (Bahar et al., 2018), (Tulak et al., 2020). Seseorang akan lebih mudah memahami dan mempraktikkan perilaku kesehatan yang lebih baik melalui audio visual dibandingkan dengan media audio dan visual saja (Sulistiyani, 2017), (Setiani \& Warsini, 2020). Pemanfaatan media video terutama masa pandemi COVID-19 membantu dalam komunikasi kesehatan. Video CTPS dan air mengalir dapat disebarluaskan melalui media sosial online (Radhiah et al., 2020) untuk menghindari kontak langsung pad masa COVID-19.

Komunikasi kesehatan dengan menggunakan metode online ini dapat dilakukan di daerah atau wilayah yang akses internet tersedia, akan tetapi pada daerah yang agak sulit dan bahkan tidak ada jaringan internet tentu menjadi sebuah hambatan sekaligus tantangan. Metode komunikasi kesehatan dengan melakukan kunjungan ke rumah warga masih menjadi alternatif selama COVID-19 dengan menerapkan protokol kesehatan secara konsisten. Oleh karena itu, pemilihan metode dan media komunikasi kesehatan harus mempertimbangkan karakteristik sasaran promosi kesehatan dan faktor lainnya. 


\section{Simpulan dan Rekomendasi}

Metode simulasi dan pemberian video tentang CTPS dengan air mengalir dapat meningkatkan pemahaman dan praktik masyarakat khususnya di kompleks perumahan dalam CTPS yang benar. Kegiatan seperti ini dapat dilaksanakan di daerah atau kota lainnya di Indonesia dengan pemilihan media dan metode yang menyesuaikan sasaran promosi kesehatan.

\section{Daftar Pustaka}

Ambarwati, E. R., \& Prihastuti. (2019). Gerakan masyarakat hidup sehat (germas) mencuci tangan menggunakan sabun dan air mengalir sebagai upaya untuk menerapkan perilaku hidup bersih dan sehat (phbs) sejak dini. Celebes Abdimas: Jurnal Pengabdian Kepada Masyarakat.

Bahar, M., Thadeus, M. S., \& Fauziah, C. (2018). Penyuluhan Perilaku Hidup Bersih Dan Sehat Dari Langkah Awal Cuci Tangan Pakai Sabun Di Komplek Perumahan Upn Kelurahan Meruyung Kecamatan Limo Kota Depok. Seminar Nasional Hasil Pengabdian Kepada Masyarakat.

Hartanti, Kurniawati, M. (2019). Perilaku Hidup bersih dan Sehat ( PHBS ) Melalui Budaya Cuci Tangan Pakai Sabun ( CTPS ). Kesehatan.

Haston, J. C., Miller, G. F., Berendes, D., Andújar, A., Marshall, B., Cope, J., Hunter, C. M., Robinson, B. M., Hill, V. R., \& Garcia-Williams, A. G. (2020). Characteristics Associated with Adults Remembering to Wash Hands in Multiple Situations Before and During the COVID-19 Pandemic - United States, October 2019 and June 2020. MMWR. Morbidity and Mortality Weekly Report. https://doi.org/10.15585/mmwr.mm6940a2

Kalsum, U. (2018). Penyuluhan Tentang Perilaku Hidup Bersih Dan Sehat Dengan Mencuci Tangan Di SMPN 13 Jakarta Timur. Jurnal Pelayanan Dan Pengabdian Masyarakat.

Kartika, M., Widagdo, L., \& Sugihantono, A. (2016). FAKTOR-FAKTOR YANG BERHUBUNGAN DENGAN PERILAKU CUCI TANGAN PAKAI SABUN PADA SISWA SEKOLAH DASAR NEGERI SAMBIROTO 01 KOTA SEMARANG. Jurnal Kesehatan Masyarakat (e-Journal).

Mulia, M. Y. (2018). PENGARUH PROMOSI KESEHATAN TENTANG CUCI TANGAN TERHADAP PENGETAHUAN IBU YANG MEMILIKI BALITA DI WILAYAH UPTD PUSKESMAS LABUAN BAJO, NUSA TENGGARA TIMUR. Jurnal Riset Kesehatan Nasional. https:// doi.org/10.37294/jrkn.v2i1.92

Mustikawati, I. S. dkk. (2016). Hubungan antara Pengetahuan mengenai Perilaku Cuci Tangan Pakai Sabun dengan Perilaku Cuci Tangan Pakai Sabun pada Ibu-ibu di 
Kampung Nelayan Muara Angke, Jakarta Utara. Forum Ilmiah.

Radhiah, S., Sanjaya, K., \& Pitriani, P. (2020). Pendampingan Cuci Tangan Pakai Sabun di SDN Al-Akbar Petobo. Jurnal Dedikatif Kesehatan Masyarakat. https://doi.org/10.22487/ dedikatifkesmas.v1i1.155

Radhika, A. (2020). HUBUNGAN TINDAKAN CUCI TANGAN PAKAI SABUN DENGAN KEJADIAN DIARE PADA BALITA DI RW XI KELURAHAN SIDOTOPO, KECAMATAN SEMAMPIR, KOTA SURABAYA. Medical Technology and Public Health Journal. https:/ / doi.org/10.33086/ mtphj.v4i1.773

Rahma Yunita Amar. (2019). Hubungan Pengetahuan Dengan Perilaku Kebiasaan Cuci Tangan Pakai Sabun Pada Siswa SD Negeri 101893 Bangun Rejo Kecamatan Tanjung Morawa. Jurnal Kesehatan Masyarakat.

Ruby, D. P., Tafwidhah, Y., \& Hidayah, M. N. (2015). Pengaruh Pendidikan Kesehatan Dengan Metode Audiovisual Terhadap Pelaksanaan Cuci Tangan Pakai Sabun Pada Anak Usia Prasekolah Di Tk Al Adabiy Kota Pontianak. Jurnal Proners.

Saputra, A., \& Fatrida, D. (2019). Health edukasi pentingnya cuci tangan pakai sabun (CTPS) di Sekolah Dasar Negeri 2 Mangunjaya. Stikesmp.

Setiani, D. Y., \& Warsini, W. (2020). Efektifitas Promosi Kesehatan Media Video dan Leaflet terhadap Tingkat Pengetahuan tentang Pencegahan Osteoporosis. Jurnal Kesehatan Holistic. https:// doi.org/10.33377/jkh.v4i2.83

Sinaga, L. R. V., Munthe, S. A., \& Bangun, H. A. (2020). Sosialisasi Perilaku Cuci Tangan Pakai Sabun Di Desa Sawo Sebagai - Bentuk Kepedulian Terhadap Masyarakat Ditengah Mewabahnya Virus Covid-19. Jurnal Abdimas Mutiara.

Sulistiyani, S. B. (2017). Efektivitas Pemberian Media Booklet Dan Video Anemia Terhadap Pengetahuan Remaja Putri Karangwuni Wates Kulon Progo Tahun 2017. Naskah Publikasi Universitas Aisyiyah Yogyakarta.

Taadi, T., Setiyorini, E., \& Amalya F, M. R. (2019). Faktor yang Berhubungan dengan Kepatuhan Cuci Tangan 6 Langkah Moment Pertama pada Keluarga Pasien di Ruang Anak. Jurnal Ners Dan Kebidanan (Journal of Ners and Midwifery). https://doi.org/10.26699/jnk.v6i2.art.p203-210

Tim BPS Covid-19 Statistical Task Force. (2020). Hasil Survei Perilaku Masyarakat Di Masa Pandemi Covid-19 (7-14 September 2020). In Perilaku Masyarakat di Masa Pandemi Covid-19 BPS RI.

Tulak, G. T., Ramadhan, S., \& Musrifah, A. (2020). EDUKASI PERILAKU CUCI TANGAN PAKAISABUN PADA SISWA UNTUK PENCEGAHAN TRANSMISI PENYAKIT. JMM (Jurnal Masyarakat Mandiri). https://doi.org/10.31764/jmm.v4i1.1702 
WHO. (2020a). Rational use of personal protective equipment for coronavirus disease 2019 ( COVID-19). World Health Organization.

WHO. (2020b). Rational use of personal protective equipment for coronavirus disease 2019 (COVID-19) and considerations during severe shortages. Who.

WHO. (2020c). Recommendations to Member States to improve hand hygiene practices to help prevent the transmission of the COVID-19 virus. World Health Organization.

World health organization (WHO). (2009). Hand hygiene technical reference manual: to be used by health-care workers, trainers and observers of hand hygiene practices. Geneva: WHO. 